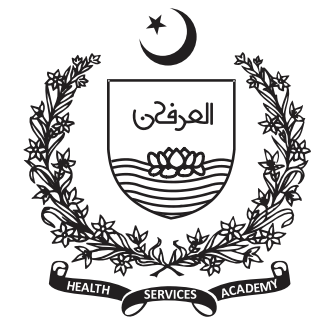

${ }^{1}$ College of Home Economics, University of Peshawar

${ }^{2}$ Home Economics, Higher Education Department, Khyber Pakhtunkhwa.

Corresponding Author: Zahin Anjum

Email:

zahinanjum@uop.edu.pk

\section{Assessment of University Students for the Risk Factors and Diabetes Profile in University of Peshawar}

\author{
Zahin Anjum ${ }^{1}$, Shaista Ali ${ }^{1}$, Amina Rahat ${ }^{1}$, Sumbla Yousaf, ${ }^{2}$ Farhat Shehzad ${ }^{1}$.
}

\section{Abstract}

Background: Among the non-communicable diseases diabetes is lifethreatening condition whose long-time complication causes heart attack, blindness, stroke and kidney failure. The objective was to determine the knowledge, attitude and practice regarding diabetes among the final year students of home economics, university of Peshawar.

Methods: This was a descriptive cross-sectional study carried out among final year university students of home economics, university of Peshawar from June to December 2019. Non-probability convenient sampling technique was used for the study. After taking written consent from individual participants a predesigned questionnaire was filled. Data was collected and analyzed by using SPSS version 16.

Results: This study included a total of 120 female students of graduate and master level. Among these students $33(27.5 \%)$ were undergraduate and 87 $(72.5 \%)$ were master level students. It was found that $39(32.5 \%)$ female students were either self-diabetics or one or more close blood related family member were suffering from diabetes. A significantly high proportion 59 $(49.2 \%)$ and $15(12.5 \%)$ female students were either overweight or obese respectively. About $59(49.2 \%)$ students were with unsatisfactory diabetics practice score, $73(60.8 \%)$ students never checked for sugar and $7(5.8 \%)$ students were found with other chronic diseases status. Interestingly only 28 (23.3\%) students know about diabetes and acquired knowledge about diabetes from nutritionists.

Conclusion: The increased frequency of obesity \& overweight, unsatisfactory diabetes score, unhealthy behavior and suboptimal attitude of female university students provided a threat of potential increase of diabetes among females in future.

Keywords: Diabetes, knowledge, attitude, practice, university, BMI

\section{Introduction}

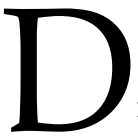
iabetes is a type of non-communicable disease that results due to insulin deficiency, responsible for metabolism of glucose (1) and characterized by increased level of glucose in blood. (2) During the last decade, the frequency of diabetes among adults increased remarkably. (3) The prevalence of diabetes among adults was 285 million at 2010, and with an increasing rate the value of diabetes among adults will reach to 439 million in 2030. (4) There are two main types of DM. The first type of diabetes, called insulin-dependent DM, results from a lack of insulin secretion by beta cells of the pancreas. The second type DM 2 in which insulin 
production is normal, but the receptor of insulin cannot capture

insulin due to many physiological changes in receptors. DM is a silent killer; many victims become aware they have DM only when they manifest complications. (5)

There are many risk factors of diabetes mellitus 2 . The unhealthy lifestyle and obesity are the predisposing factors of diabetes among adults. Genetics also play an important role in acquiring diabetes. (6) The recent trends of unhealthy lifestyle among university students such as the use of junk foods, drug addiction, smoking and obesity have left the students at the risk of developing diabetes. (7) Many studies reported diabetes cases among university students. $(8,9)$ The present study has been designed to assess the knowledge, attitude and practices of university students regarding diabetes and to provide information about the possible risk frequency diabetes in future based on the collected information.

\section{Methodology:}

This was a descriptive cross-sectional study carried out among final year university students of home economics, university of Peshawar from the duration of June to December 2019. Non-probability convenient sampling technique was used for the study. After taking written consent from individual participants a predesigned questionnaire was filled. The questionnaire consists of questions regarding demography, attitude toward diabetes, practice, control measures and knowledge level of students toward diabetes. Data was collected and analyzed by using SPSS version 16.

\section{Results:}

This study included a total of 120 female students of graduate and master level. Among these students 33 $(27.5 \%)$ were undergraduate and $87(72.5 \%)$ were master level students. A total of $10(8.33 \%)$ female students were married and 110 (91.6\%) were unmarried. A total $84(70 \%)$ students were belonging to middle socio-economic class (Table 1). The Majority of female students $104(86.7 \%)$ were belonging to the city of Peshawar (Table 2). It was found that $81(67.5 \%)$ students were non-diabetics and have no close blood relative suffering from diabetes, however 39 (32.5\%) female students were either self-diabetics or one or more closer family member were suffering from diabetes.
Table 1. Socio-demographic profile of study participants

\begin{tabular}{|c|c|c|c|c|}
\hline \begin{tabular}{|l|} 
Marital \\
status
\end{tabular} & $\begin{array}{l}\text { Education } \\
\text { level }\end{array}$ & $\begin{array}{l}\text { Socioeconomic } \\
\text { status }\end{array}$ & Frequency & \begin{tabular}{|l|} 
Percent \\
age $\%$
\end{tabular} \\
\hline \multirow[t]{6}{*}{ Married } & \multirow[t]{3}{*}{ BS } & Low & 0 & 0 \\
\hline & & Middle & 0 & 0 \\
\hline & & Satisfactory & 1 & 0.83 \\
\hline & \multirow[t]{3}{*}{ Master } & Low & 1 & 0.83 \\
\hline & & Middle & 5 & 4.2 \\
\hline & & Satisfactory & 3 & 2.5 \\
\hline \multicolumn{3}{|l|}{ Sub Total } & 10 & 8.33 \\
\hline \multirow[t]{6}{*}{ Unmarried } & \multirow[t]{3}{*}{ BS } & Low & 3 & 2.5 \\
\hline & & Middle & 9 & 7.5 \\
\hline & & Satisfactory & 20 & 16.7 \\
\hline & \multirow[t]{3}{*}{ Master } & Low & 8 & 6.66 \\
\hline & & Middle & 10 & 8.33 \\
\hline & & Satisfactory & 60 & 50 \\
\hline \multicolumn{3}{|l|}{ Sub Total } & 110 & 91.6 \\
\hline \multicolumn{3}{|l|}{ Total } & 120 & 100 \\
\hline
\end{tabular}

Table 2. Frequency distribution of study participants with respect to region

\begin{tabular}{|l|c|c|}
\hline Address & Frequency & Percentage (\%) \\
\hline Bannu & 002 & 1.7 \\
\hline Charsadda & 006 & 5.0 \\
\hline Chitral & 002 & 1.7 \\
\hline DI Khan & 002 & 1.7 \\
\hline Hazara & 002 & 1.7 \\
\hline Karak & 001 & 0.8 \\
\hline Mardan & 001 & 0.8 \\
\hline Peshawar & 104 & 86.7 \\
\hline
\end{tabular}

The study provided that $9(7.5 \%)$ female students have family members using insulin for treatment (Table 3 ). A significantly high proportion 59 (49.2\%) and 15 $(12.5 \%)$ female students were either overweight or obese respectively (Figure 1). Out of 120 female university students participated in the study 59 (49.2\%) were with unsatisfactory diabetics practice score, $73(60.8 \%)$ students never checked for sugar and $7(5.8 \%)$ students were found with other chronic diseases status (Table 4). Interestingly majority 28 $(23.3 \%)$ students know about diabetes and acquired knowledge about diabetes from nutritionists either directly or in TV program (Table 5). 
Table 3. Diabetes status of study participants and blood relations

\begin{tabular}{|c|c|c|c|c|c|}
\hline $\begin{array}{l}\text { Diabetic } \\
\text { patients in } \\
\text { blood relation }\end{array}$ & $\begin{array}{l}\text { Type of } \\
\text { treatment }\end{array}$ & Diagnostic mode & $\begin{array}{l}\text { Duration of diabetes } \\
\text { in months }\end{array}$ & Frequency & Percentage $\%$ \\
\hline $\mathrm{NO}$ & NA & NA & NA & 81 & 67.5 \\
\hline \multicolumn{4}{|c|}{ Sub total } & 81 & 67.5 \\
\hline \multirow[t]{8}{*}{ Yes } & \multirow[t]{4}{*}{ Insulin } & \multirow[t]{2}{*}{ Incidental } & $\leq 5$ & 1 & 0.833 \\
\hline & & & $5-12$ & 3 & 2.5 \\
\hline & & \multirow[t]{2}{*}{ symptomatic } & $\leq 5$ & 2 & 1.66 \\
\hline & & & $5-12$ & 3 & 2.5 \\
\hline & \multirow{4}{*}{$\begin{array}{l}\text { Non- } \\
\text { Insulin }\end{array}$} & \multirow[t]{2}{*}{ Incidental } & $\leq 5$ & 1 & 0.833 \\
\hline & & & $5-12$ & 11 & 9.16 \\
\hline & & \multirow[t]{2}{*}{ symptomatic } & $\leq 5$ & 3 & 2.5 \\
\hline & & & $5-12$ & 15 & 12.5 \\
\hline \multicolumn{4}{|c|}{ Sub total } & 39 & 32.5 \\
\hline \multicolumn{4}{|c|}{ Total } & 120 & 100 \\
\hline
\end{tabular}

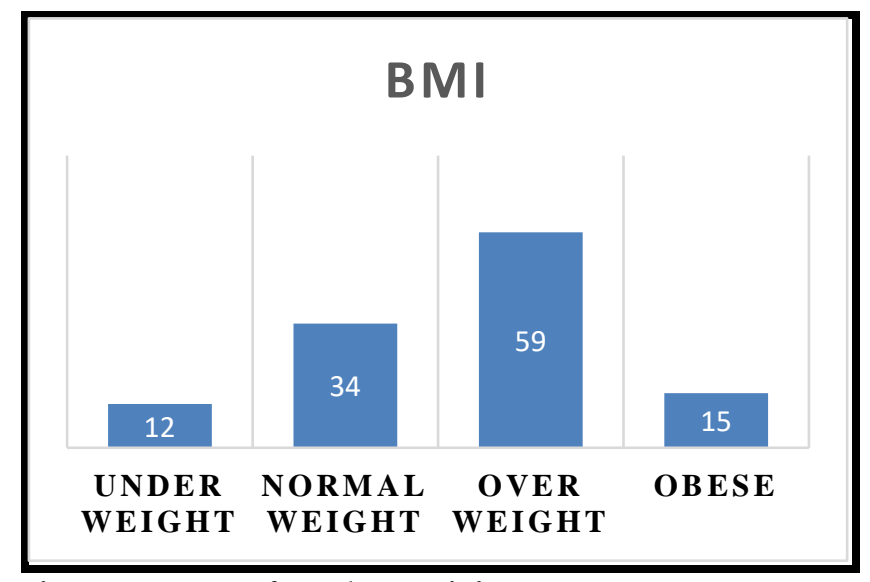

Figure 1. BMI of study participants

Table 4. Practice and attitude of study participants regarding diabetes

\begin{tabular}{|c|c|c|c|}
\hline $\begin{array}{l}\text { Practice \& } \\
\text { Attitude } \\
\text { toward } \\
\text { diabetes }\end{array}$ & Description & Frequency & $\begin{array}{c}\text { Percentage } \\
(\%)\end{array}$ \\
\hline \multirow{4}{*}{$\begin{array}{l}\text { Diabetes } \\
\text { practice score } \\
\text { (Practice } \\
\text { level) }\end{array}$} & \multicolumn{3}{|l|}{ Score level } \\
\hline & Good & 33 & 27.5 \\
\hline & Satisfactory & 28 & 23.3 \\
\hline & $\begin{array}{l}\text { Un- } \\
\text { Satisfactory }\end{array}$ & 59 & 49.2 \\
\hline \multirow{4}{*}{$\begin{array}{l}\text { Self-control of } \\
\text { diseases }\end{array}$} & \multicolumn{3}{|l|}{ Control Status } \\
\hline & $\begin{array}{l}\text { Always in } \\
\text { good control }\end{array}$ & 23 & 19.2 \\
\hline & $\begin{array}{l}\text { Never } \\
\text { Checked }\end{array}$ & 73 & 60.8 \\
\hline & $\begin{array}{l}\text { Randomly } \\
\text { Control }\end{array}$ & 24 & 20.0 \\
\hline
\end{tabular}

\begin{tabular}{|l|l|c|c|}
\hline \multirow{2}{*}{$\begin{array}{l}\text { Clinical test } \\
\text { arrangement }\end{array}$} & \multicolumn{3}{|l|}{ Test detail } \\
\cline { 2 - 4 } & $\begin{array}{l}\text { Not tested } \\
\text { yet }\end{array}$ & 56 & 46.7 \\
\cline { 2 - 4 } & Yes & 64 & 53.3 \\
\hline \multirow{2}{*}{$\begin{array}{l}\text { Other chronic } \\
\text { diseases }\end{array}$} & Descriptions & \multicolumn{2}{|c|}{} \\
\cline { 2 - 4 } & No & 113 & 94.2 \\
\cline { 2 - 4 } & Yes & 7 & 5.8 \\
\hline
\end{tabular}

Table 5. Source \& Knowledge of awareness \& its follow-up ( $\mathrm{N}=120)$

\begin{tabular}{|l|c|c|}
\hline Source & Frequency & Percentage (\%) \\
\hline Doctor & 17 & 14.2 \\
\hline $\begin{array}{l}\text { Electronic \& } \\
\text { Print Media }\end{array}$ & 14 & 11.7 \\
\hline Family Doctor & 04 & 3.3 \\
\hline $\begin{array}{l}\text { Friend \& } \\
\text { Family }\end{array}$ & 14 & 11.7 \\
\hline $\begin{array}{l}\text { Health } \\
\text { Educator }\end{array}$ & 18 & 15.0 \\
\hline Nurses & 08 & 6.7 \\
\hline Nutritionist & 28 & 23.3 \\
\hline Social Media & 17 & 14.2 \\
\hline
\end{tabular}

\section{Discussion:}

This study was carried out among university female students in order to determine the risk factor and diabetes profile among the young educated females who will be future family builders and potential risk group of diabetes having their abundant access to junk food and others unhealthy life-style. Inspite of many 
limitation in term of time, budget the findings of the study were quite interesting and worthful.

This study showed that $39(32.5 \%)$ female university students were having one or more close family member suffering from diabetes. Another study published in 2006 in international journal of diabetes in developing countries shows the prevalence of diabetes in families $18.24 \%$. (10) The increased level of diabetes in families of present study participants may be due to low sample size affect or low validity of verbal confirmation of the diseases status.

Another finding of this study was that 59 (49.2\%) female students were overweight and 15 (12.5\%) obese that considered as potential risky group for developing diabetes. The finding of this study was in accordance to other studies where the rate of overweight and obesity was high among female students. (11-13)

The present study it was found that 59 (49.2\%) female students were with unsatisfactory diabetics practice score measured through different healthy life-style behavioral factors and $73(60.8 \%)$ students never checked for sugar. The findings of this study were similar with the findings of other two studies where the majority study participants were also with unsatisfactory diabetics practice score and with poor attitude to control diabetes. $(14,15)$ This study also showed that 28 (23.3\%) study participants were having knowledge about diabetes. The sources of knowledge about diabetes were assessed nutritionists either directly or in TV program. Other studies also justify the fact that females are more sensitive to nutritionist guideline and approached nutritionist more frequently with fear of obesity and physical look maintenance.

\section{Conclusion:}

The frequency of diabetes was found high among university students and increasing with the passage of time. The increased frequency of obesity \& overweight, unsatisfactory diabetes score, unhealthy behavior and suboptimal attitude of female university students found in this study provided a potential threat of diabetes among female in future. However the nutritionist intervention can be beneficial for sensitizing female toward diabetes and its complication.

\section{Acknowledgment:}

The authors are thankful to the head of Home economics Department, University of Peshawar, for providing permission to carry out this study among female students.

\section{Conflict of Interest:}

None

\section{References:}

1. Leese HJ and Mansford K. The effect of insulin and insulin deficiency on the transport and metabolism of glucose by rat small intestine. The Journal of physiology. 1971; 212: 819-38.

2. Baynes HW. Classification, pathophysiology, diagnosis and management of diabetes mellitus. J diabetes metab. 2015; 6: 1-9.

3. Choi YJ, Cho YM, Park CK, et al. Rapidly increasing diabetes-related mortality with socio-environmental changes in South Korea during the last two decades. Diabetes research and clinical practice. 2006; 74: 295-300.

4. Guariguata L, Whiting DR, Hambleton I, Beagley J, Linnenkamp $U$ and Shaw JE. Global estimates of diabetes prevalence for 2013 and projections for 2035. Diabetes research and clinical practice. 2014; 103: 137-49.

5. Alberti KGMM and Zimmet PZ. Definition, diagnosis and classification of diabetes mellitus and its complications. Part 1: diagnosis and classification of diabetes mellitus. Provisional report of a WHO consultation. Diabetic medicine. 1998; 15: 539-53.

6. Martín-Timón I, Sevillano-Collantes C, Segura-Galindo $\mathrm{A}$ and del Cañizo-Gómez FJ. Type 2 diabetes and cardiovascular disease: have all risk factors the same strength? World journal of diabetes. 2014; 5: 444.

7. Aceijas C, Waldhäusl S, Lambert N, Cassar S and BelloCorassa R. Determinants of health-related lifestyles among university students. Perspectives in public health. 2017; 137: 227-36.

8. Khan N, Gomathi KG, Shehnaz SI and Muttappallymyalil J. Diabetes mellitus-related knowledge among university students in Ajman, United Arab Emirates. Sultan Qaboos University Medical Journal. 2012; 12: 306.

9. Pengpid S, Peltzer K, Kassean HK, Tsala JPT, Sychareun $\mathrm{V}$ and Müller-Riemenschneider F. Physical inactivity and associated factors among university students in 23 low-, middle-and high-income countries. International journal of public health. 2015; 60: 539-49.

10. Jali M and Kambar S. Prevalence of diabetes amongst the family members of known diabetics. Int J Diab Dev Ctries. 2006; 26: 81-5. 
11. Al Qauhiz NM. Obesity among Saudi Female University Students: Dietary Habits and Health Behaviors. The Journal of the Egyptian Public Health Association. 2010; 85: 45-59.

12. van Zandvoort M, Irwin JD and Morrow D. Co-active coaching as an intervention for obesity among female university students. International Coaching Psychology Review. 2008; 3: 191-206.

13. Sirang Z, Bashir $\mathrm{HH}$, Jalil B, et al. Weight patterns and perceptions among female university students of Karachi: a cross sectional study. BMC Public Health. 2013; 13: 1-8.
14. Eshah NF. Lifestyle and health promoting behaviours in Jordanian subjects without prior history of coronary heart disease. International Journal of Nursing Practice. 2011; 17: 27-35.

15. El-QuDAh JM. Dietary knowledge among female diabetic patients in Amman, Jordan. Current Research in Nutrition and Food Science Journal. 2016; 4: 107-13.

16. Dillinger DP. A Guide to Acquiring Healthy Nutrition and Fitness Habits for College Students: Preventing Diabetes, Hypertension, Coronary Heart Disease, and Stroke. 2012. 